\title{
(German) Universities as multiple hybrid organizations
}

\author{
Bernd Kleimann ${ }^{1}$ \\ Published online: 26 October 2018 \\ (C) The Author(s) 2018
}

\begin{abstract}
The paper claims that the organizational character of the (German) university can be comprehended best with the aid of the concept "multiple hybrid organization." To corroborate this claim, I reconstruct two lines of argument that have dominated the discourse on the organizational nature of the German university so far. This discourse has only started in the late 1980s and early 1990s in the wake of new public management emphasizing that the reform of higher education governance has turned German universities into corporate actors (Meier 2009; Krücken and Meier 2006). At the same time, voices have risen advocating the singularity of the university and contrasting it to bureaucratic and corporate forms of organization. The paper starts by outlining these two strands of argumentation: the first highlights the organizational normality of the German university, the next its singularity. Against this background, I shall argue that both positions can be integrated if we rely on the term "multiple hybrid organization." This concept is integrated into the systems theory concept of formal organization which serves as a theoretical means for analyzing organizations at large. The new concept of multiple organizational hybridity demonstrates its usefulness in showing that the structural particularity of the German university is rooted in numerous frictions pertaining to all its organizational structures.
\end{abstract}

Keywords German university · Formal organization · Hybrid organization · Organization sociology $\cdot$ Systems theory

Bernd Kleimann

kleimann@dzhw.eu

1 German Centre for Higher Education Research and Science Studies (Deutsches Zentrum für Hochschul- und Wissenschaftsforschung DZHW), Lange Laube 12, 30159 Hannover, Germany 


\section{Introduction}

The paper claims that the organizational character of the (German) ${ }^{1}$ university can be comprehended best with the aid of the concept "multiple hybrid organization." To corroborate this claim, I reconstruct two lines of argument that have dominated the sociological discourse in Germany on the organizational nature of the university so far. This discourse has only started in the late 1980s and early 1990s in the wake of new public management emphasizing that the reform of higher education governance has turned German universities into corporate actors (Meier 2009; Krücken and Meier 2006). At the same time, voices have risen advocating the singularity of the university and contrasting it to bureaucratic and corporate forms of organization.

The paper starts by outlining these two strands of argumentation: the first highlights the organizational normality of the German university, the next its singularity. Against this background, I shall argue that both positions can be integrated if we rely on the term "multiple hybrid organization."

In paragraph 3, systems theory's concept of formal organization is introduced as a theoretical means for analyzing organizations at large. Complementing this concept, the next paragraph unfolds the term "multiple hybrid organization." The next step shows that the structural particularity of the German university is rooted in numerous frictions pertaining to all its organizational structures. This turns the German university into a multiple hybrid organization.

As this concept of multiple hybridity provides a heuristic model of the (German) university, it contributes to organization sociology and higher education research in three ways: first, it specifies the general notion of organizational hybridity by referring to systems theory's model of formal organizations. Second, it deepens the understanding of the internal structures of universities in general, and third, it calls attention to the specific contradictions and tensions which are characteristic of German and - most likely - many other universities around the globe. The closing paragraph sums up and raises questions for future research.

\section{The (organizational) character of the (German) university}

In its early stages, the German discourse on the social nature of the university has been dominated by the notion "institution" (Schelsky 1963; Arnold 1970). Today, considering the university an institution is still popular among many scholars (Stichweh 2001; Baecker 2011; von Wissel 2007; Schimank 2008; Rehberg 2009; Meier 2009; Adam et al. 2010; Stichweh 2010) - partly due to the neo-institutionalist "renaissance" of institutions (DiMaggio and Powell 1991) and the claim of a worldwide diffusion of the university model (Meyer et al. 2007; Meyer et al. 2006; Krücken and Meier 2006). In the context of higher education, "institution" usually denotes a common and stable conception (Zucker 1977) of the

\footnotetext{
${ }^{1}$ The arguments which are developed in the following and which support the multiple hybrid character of the German university are likely to be applicable to many research universities around the globe as well—at least if these organizations are equally engaged in teaching and (multidisciplinary) research and show a considerable amount of, e.g., state influence, professorial autonomy (through constitutionally guaranteed freedom of teaching and research), and student participation. However, as the empirical basis of this article is the German higher education system, it is advisable to limit knowledge claims to the German system in the first place while at the same time encouraging further research on the applicability of the term "multiple hybridity" on universities worldwide (cf. section 5).
} 
constitutive functions and features of the university. Hence, universities are institutions in their capacity as highly generalized expectation structures.

In contrast to that, the university has been referred to as an organization only since two decades. Still in 2001, the sociologist R. Paris asserted that organization sociology in Germany has rarely dealt with universities (Paris 2001). By now, however, studies explicitly address the organizational character of the university (Pellert 1999; Reichwald 2000; Stichweh 2005; Enders 2008; Meier and Schimank 2010; Hüther 2010; Wilkesmann and Schmid 2012). This is due to changes in the wake of new public management (Huber 2012) and the expansion of higher education. The university has turned into an actor with strategic agency (Krücken and Meier 2006; Meier 2009; de Boer et al. 2007) possessing an enlarged autonomy (Bogumil et al. 2013) and facing an increasing number of tasks and duties (Schimank 2001; Schreiterer 2010). These circumstances have fostered the formerly uncertain claim (Pellert 1999; Braun 2001; Nickel 2007) that the university definitely is an organization.

Hence, these days, the university is seen as an institution and as an organization. As an institution, it represents a stable, deeply rooted cognitive expectation structure (Hechler and Pasternack 2012; von Wissel 2007; Kerr 2001; Stichweh 1994) that figures as a widespread cultural model (Meyer et al. 2006: 9ff.). This model defines essential features of the universityas-an-organization. The features do not have to be consistent as it is just the internal fragmentation of the university that secures its historical stability (Rehberg 2009; Mazza et al. 2008). But how can we describe these features and integrate them in a comprehensive organizational model?

Browsing the higher education discourse, two answers whose conceptual nature is idealtypical in the Weberian sense (Weber 1968) and which embody extreme positions that in this pure form do not appear in the literature can be derived. Both have a subliminal normative core. The normality argument claims (in its stronger version) that the university is an ordinary organization resembling corporate businesses or bureaucratic entities. In a weaker version, it holds that the university at least is about to turn from an incomplete organization (an arena of loosely coupled professionals) into a complete one (Brunsson and Sahlin-Andersson 2000²). This means that universities are empowered to manage their affairs autonomously and to set up according tasks, identities, and management structures (Ahrne and Brunsson 2009; Enders 2008; Clark 1998). The consequence is that universities have turned into organizations similar to corporate firms or public bureaucracies.

At the bottom of this assumption lies an implicit normative model that takes public administrations and corporate enterprises to be prototypes of formal organizations (Luhmann 1988; Bleiklie and Kogan 2007). This model is so deeply rooted in today's society that even organization sociology has failed to explicitly depict firms and bureaucracies as special types of organizations (Apelt and Tacke 2012).

In contrast to this, a second assumption argues in support of the organizational singularity of the university. According to this argument, the university is a "highly odd" (Schimank 2008) type of organization (Dörre and Neis 2010; Krücken 2011) featuring particular structures and constituting a particular societal institution (Baecker 2011). Supporters of this argument (Huber 2012; Hüther 2010; Enders 2008; Stichweh 2005; Laske and MeisterScheytt 2003) would resolutely affirm Christine Musselin's question “Are Universities

\footnotetext{
${ }^{2}$ Seeber et al. (2015) have investigated with regard to 26 European universities to what extent these universities resemble the characteristics of a complete university and whether varying forms of the university can be related to modernization policies, national system characteristics, or organizational features.
} 
Specific Organizations?" (Musselin 2007). They emphasize that the university can only be understood as a deviation from a global model of formal organization (Enders and Fulton 2002) and does not fit into the functionalistic or bureaucratic idea of organizations, but shows organizational particularities in different structural respects. Hence, the alleged "normalization" or "organizationalization" of the university proves to be a rather superficial phenomenon nested in the rhetoric of legitimization.

Yet, both arguments can be reconciled as they operate on different levels of abstraction. A sufficiently abstract model of organization can adopt the normality argument's claim that the university constitutes a regular organization. This implies that our model does not promote a normative idea of what the university is or should be, but functions as a heuristic analysis tool enabling an investigation of the full range of different types of organizations.

At the same time, the singularity argument claims that the organizational character of the university can be grasped by distinguishing it from an abstract model of organization. In this perspective, the features of an organization are taken as variables which allow manifestations to a varying extent (Huber 2005). However, a fulfillment to a rather low degree would not permit to diagnose an incomplete organization, but speak in favor of the existence of a special type of organization. Therefore, the searched-for organization model must offer a general, comprehensive concept of organization which is able to grasp the singularity of the university without attributing it to deviance from a normative model of organization.

\section{Formal organization}

The key to such a model is the reformulation of the two arguments with the aid of Luhmann's systems theory (Luhmann 1964; Luhmann 2006). Luhmann views organizations as formally organized social systems which reproduce themselves through the communication of decisions (Luhmann 1988). Decisions are the basic elements of organizations. They are choices between contingent alternatives (Grunow 2004) that are attributed to organization members. Compared to "simple" actions, these organizational decisions are subject to relatively high pressure (Luhmann 1984; Luhmann 2009) induced by the rules each member has to comply with once she has joined the organization. This implies that each action of an organization member can be observed as either compliant with or departing from the organization's rules - so that even getting a cup of coffee may be noticed as a decision to increase one's performance or to refuse work (Drepper 2003).

The probability or improbability of decisions within organizations is determined by the organization's structures which Luhmann - referring to Simon (1947) — calls "decision premises" (Luhmann 2006: 222ff.). Decision premises limit the leeway of an indefinite number of future decisions. Luhmann distinguishes between four types.

Decision programs (i.e., goal and conditional programs) determine how decisions are to be made and which decisions are compliant with the organization's rules (Luhmann 1964, 1992, 2006). Goal programs define the purposes and ends of the organization, i.e., the targeted output, without stipulating the means. Consequently, all means which are not forbidden are allowed. Furthermore, goal programs determine which functional systems the organization refers to (Luhmann 1998; Schimank 2005)-for example, companies to the economic, armies to the military system, etc. (Tacke 2001; Luhmann 2006). Organizations follow the binary code of one functional system (e.g., "true/untrue" in science) and execute its programs (e.g., scientific theories and methods). 
Conditional programs are the second type of decision programs. They consist in if-thenrules determining specific reactions to clearly defined triggers (e.g., the application to enroll in a university). As they specify the legitimate means to be chosen under certain circumstances, all means that are not allowed are strictly forbidden. Usually, goal and conditional programs are intertwined. A publicly funded research project, for example, serves the goal of scientific knowledge production and is, at the same time, liable to the rules of grant application, budget control, and exploitation of results.

The next fundamental organizational structure is constituted of the communication channels. Communication channels - like hierarchical or project structures (Kühl 2013) - define who is entitled to issue an order to whom and who has to report to whom. They determine how the offices and positions within the organization are interrelated, they separate the organization from its environment, and divide it into distinct organizational units (Luhmann 2006). Kühl distinguishes three types of communication channels which often are combined: hierarchy allocating rights and responsibilities vertically and horizontally, co-signature regulating sequential decision-making of different positions and units, and project structures which partially and temporarily transcend the regular chain of command (Kühl 2013).

The third organizational structure is personnel. Staff has a structural quality insofar as features of organization members (knowledge, skills, preferences, age, gender, performance levels, etc.) have an impact on how decisions are made (Luhmann 2006; Kühl 2013). Additionally, organization members know about the features of colleagues and adjust their own decision-making to the expected decisions of their peers (Drepper 2003). Therefore, the decision on who is supposed to become a member of the organization is of utmost importance (Luhmann 1964, 1988, 1998, and 2006; Kühl 2013).

While these three decision premises can be decided upon by the organization, the organizational culture partially transcends the reach of organizational control. The organization might formally present itself in symbols, buildings, or appearances and demand specific attitudes or a certain demeanor and, thus, shape the visible side of the organization (formal culture). But no organization can determine the whole range of action patterns and routines, evaluative attitudes, and cognitive schemes of its members (Kühl 2013) which are embedded in the history of the organization and implicitly articulated through different media (Sathe 1985). So the informal culture is an "undecidable" decision premise (Luhmann 2006: 240), and its elements are usually not discussed explicitly lest they are exposed to the risk of rejection.

In the following, I will concentrate on the first three basic structures as the core elements of the concept of formal organization. This concept implies that a social system can be considered to be a formal organization provided that it is able to control its own decidable structures at least to a certain degree (Luhmann 2006). Therefore, the decidable structures are necessary conditions for applying the term "organization" and, at the same time, variables whose manifestations vary according to the degree of organizational autonomy.

\section{(Multiple) Hybrid organizations}

In how far is this concept of formal organization apt to grasp the organizational character of the German university? First of all, it reconciles the normality and the singularity argument. From the normality argument, it adopts the thought that there are necessary conditions for formal organizations. These conditions are the organizational structures I have just explained. At the 
same time, the model integrates the singularity argument through endorsing that the particular organizational character of the university is rooted in the way in which the organizational structures are manifested. Following this, the particularity of the (German) university consists of its specific combination of organizational structures.

If we apply this model of formal organization to the university, a problem arises. Systems theory reckons that organizations are associated exclusively with one functional system:

"Usually, organizations in modern society are specialized with regard to one of societies' functional systems: companies and the banks with regard to the economy, churches to the religious systems, schools to the education system, political parties and advocacy groups to the political system." (Luhmann 2009: 217)

Obviously, this does not apply to the contemporary German university as it is engaged in both teaching and research at the same time and to the same extent (Schimank 1995). Accordingly, Luhmann declares:

"Universities are a rare exception. As the principle of unity of research and teaching claims, they serve science and education at the same time." (Luhmann 2009: 217)

This "organizational coexistence" of both tasks (Braun and Schimank 1992) is institutionalized with reference to the Humboldtian myth of the unity of teaching and research (Ash 1999) and seen as the defining feature of the university (Stichweh 2005; Schimank 1995).

Admittedly, systems theory concedes that almost all organizations have to deal with different functional systems. For instance, almost every organization is engaged in economic transactions or regulated by law. Nonetheless, producing relevant output for two functional systems at the same time remains - in contrast to the evolutionary advantages of specialization - an exception. In the case of the (German) university, this has led to its characterization as a "changeling" (Rehberg 2009: 16), an anomalous (Luhmann 1992; Huber 2005), singular (Stichweh 2005), extravagant, or even paradoxical (Luhmann 2006) organization.

In order to account for this theoretical problem, it makes sense to amend the understanding of organization by introducing the notion "hybrid organization." This notion is widespread in academic discourse on the "third sector" where it denotes the tension between profit and nonprofit-orientation (Simsa 2001; Billis 2010). According to Ciesielska, a hybrid organization is a "place where heterogeneous institutions, logics of actions, ideologies and identities meet" (Ciesielska 2010: 6). In a similar way, other authors emphasize the multiplicity of organizational forms deviating from traditional templates (Boccardelli et al. 2018), the heterogeneity of institutional logics (Mongelli et al. 2017; Pache and Santos 2013), or the plurality of system relations (Bode 2003). In their seminal paper on organizational identity, Albert and Whetten (1985; Whetten 2006) have already applied the term "hybrid organization" to the university due to its twofold identity (as a church and as a company). Other authors have highlighted the hybrid funding of the university (state alimentation and selling research and teaching products; Mouwen 2000; Bijsterveld and van Mouwen 2001) or the tension between creativity and efficiency in this "ambidextrous organization" (Tahar et al. 2012).

Even if this concept of organizational hybridity is still rather vague, it can be integrated in systems theory by focusing on the parallelism of equivalent organizational goal programs.

\footnotetext{
${ }^{3}$ Translation of citations by the author.
} 
This means that the university can be viewed as a hybrid organization because it pursues two goal programs at the same time, teaching and research, which connects it equally to the research and to the education system.

However, another conceptual refinement is advisable as the structural inconsistencies are not limited to the university's goal programs. These tensions are not only minor irritations (which all organizations exhibit), but relevant to the organization's operations and survival (Kleimann 2016). Many of them are interdependent because the frictions pertaining to one organizational structure impact on other organizational structures as well (Battilana and Lee 2014). Hence, an organization can be called a multiple hybrid organization if it exhibits inconsistencies with regard to all its organizational structures.

My claim is now that this pervasive hybridity is the determining feature of the German university - and the reason for its organizational particularity. If the university in general already is an "inconsistent institution" (Kerr 2001: 14), the German university is downright "built on contradictions" (Rehberg 2009: 12) - and, accordingly, a multiple hybrid organization.

\section{The German university as a multiple hybrid organization}

To corroborate this claim, this paragraph focuses on the inconsistencies of the university's formal organizational structures, i.e., of its decision programs, communication channels, and personnel.

\section{Decision programs}

Regarding the decision programs of the German university, four aspects stand out: (1) the different systemic contexts the university has leant onto in its evolutionary history, (2) the frictions springing from the duality of research and teaching, (3) the recent increase of new and often contradicting tasks, and (4) the notorious rivalry of logics between the goal-programmed academic sector and the conditional-programmed administrative sector.

(1) From the historical outset, the institutional core of the occidental university has been academic teaching. However, in its history, the university has leant onto other societal contexts as well (Stichweh 2009). Clerical control was prevalent from the foundation of the Parisian university onwards up to the fifteenth century. Due to the formation of territorial states, the universities' orientation then shifted towards political entities, and under the influence of (enlightened) absolutism, it became a public institution with the obligation to train civil servants (Müller 1996). Beginning with the second half of the eighteenth century and driven by the metamorphosis of the German "family university" into a meritocratic "performance university" (Paletschek 2001: 229), the reference to the emerging science system was strengthened. In the twentieth century, finally the economic system has become relevant to the university (Etzkowitz et al. 1998). Henceforth, input and output of the university could be interpreted in an economic perspective-e.g., the output of academic mass education as the formation of human capital. However, in Germany, the impact of the economic system still is far from being as strong as the influence of state control. 
(2) As a consequence of this evolutionary history, two main goal programs dominate the German university today: teaching as the historically prior, deeply institutionalized purpose and the "younger" research whose significance for funding and reputation today is paramount. This twoness of purpose is legitimized and codified in all higher education acts of the 16 German states and constitutes an unalienable component of the universities' identity. However, the relationship between teaching and research inevitably is a competitive relationship - a fact Humboldt's maxim of the unity of teaching and research can only partly conceal (Schimank 1995). Both purposes compete for resources like time, money, positions, or reputation which are at the same time prerequisites and results of university performance. Above all, this causes new role conflicts-for example, for academic staff who is torn between research performance orientation and coping with the teaching load. ${ }^{4}$

Another well-known problem of the two main goal programs is the fact that the university cannot guarantee a successful outcome of teaching and research as both are "unclear technologies" (Cohen et al. 1972; Luhmann and Schorr 1982). Both goal programs lack clear-cut cause-effect-connections and defy hierarchical and bureaucratic control (Musselin 2007). With regard to research, it is impossible to plan groundbreaking scientific insights and discoveries, and only the experts as representatives of the scientific community (and not the university) are able to define scientific problems and the theoretical and methodological ways to tackle them (Mintzberg 1989). With regard to teaching, the waywardness of psychic systems untermines the attempt to initiate learning processes through organizational decisions. For these reasons, success in teaching and research cannot be achieved by orders, and even the reproduction of many results is extremely difficult (Meyer and Rowan 1977; Musselin 2007).

(3) Another friction in the university's goal programs is caused by the remarkable increase of tasks the university is supposed to take on without a proportionate increase of resources (Schreiterer 2010; Schimank 2001). The spectrum of formally codified and informally expected new tasks encompasses knowledge and technology transfer, gender mainstreaming, family friendliness, personnel development, diversity management, institutional openness for nontraditional students, service learning provision, integration of refugees, sustainable resource management, or strengthening democratic attitudes. This increase of tasks exacerbates the goal conflict between teaching and research and converts German universities - to put it pointedly_into "failing department stores" (Schimank 2001: 229). Moreover, several of the new purposes contradict each other: the university is torn between public heteronomy and corporative autonomy, research and teaching, mass and elite education, democratic and etatist traits, labor market-oriented employability and science-oriented curiosity, basic and applied research (Rehberg 2009), long-term sustainability and short-term effectiveness, preservation of societal values and initiation of societal change, international and regional impact, and so forth.

\footnotetext{
${ }^{4}$ Additionally, a variety of new tasks - often labeled as third mission — has come up in recent years. However and in contrast to teaching and research, third mission so far is no academic task of equal rank - due to different reasons. First, the concept is highly ambiguous and carries different meanings; second, it is not rooted in the same way in the German constitution as teaching and research; and third, it is not yet perceived as a taken-for-granted duty by the professorial profession. These conditions in combination with political federalism explain why there is - at least so far - no standard definition of "third mission" in the 16 German states' higher education legislation.
} 
(4) Another structural contradiction relates to the dominance of goal programs in the academic sector and the prevalence of conditional programs in the administrative sector. While the success of teaching and research cannot be guaranteed by rules, administrative processes can be determined successfully by linking defined inputs to defined operational procedures (e.g., the enrollment process). The diverging logics of both areas make them "platonic foes" (Daxner 1999: 55) facing numerous frictions and misunderstandings. This applies not only to German universities, but to higher education worldwide (vgl. Lewis and Altbach 1996; Delbecq et al. 2013).

\section{Communication channels}

The communication channels of German universities show specific features as well. Four aspects are worth mentioning: the friction between heteronomy and autonomy (1), the double hierarchy (2), the loose coupling of organizational units (3) and the power of the professoriate (4).

(1) The first aspect is rooted in the friction between the universities' growing autonomy on the one hand and the remaining influence of the state on the other. An indicator for this is the legal status of universities: in most of the 16 federal states, universities are state institutions as well as statutory corporations (i.e., legal entities that are governed by their members; von Coelln 2011) and, thus, subject to state governance as well as to academic self-governance. Against this backdrop, the heteronomy of the German university is due to a broad range of legal statutes which either exclusively apply to universities (teaching load regulation, etc.) or to state institutions in general (budget law, civil servant act, etc.). The exuberance of these rules has given rise to complaints that the German universities are inexorably overgrown by state regulations (Schimank 2001). The extent of this heteronomy becomes obvious in comparison to private businesses - for example, regarding the change of goal programs. While enterprises can change their products and service at will, no public university in Germany could dismiss teaching or research as organizational goals.

At the same time, universities have significantly gained autonomy in the wake of new public management as a lot of decisions have been transferred from the ministry to university management (Hüther 2010; Bogumil et al. 2013). Today, universities are expected to actively manage their own business and to make farreaching decisions on a broad range of issues. One structural indicator of these new responsibilities is the increasing number of new academic professionals (Kehm and Teichler 2013).

(2) A second friction of the German university's communication channels is its double hierarchy (Stichweh 2005; Blümel et al. 2011). On the one hand, there is academic self-governance with its multi-layer system of committees and individual authorities (Kern 2005); on the other, the administrative hierarchy with its bureaucratic line-structure. While academic self-governance incorporates institutionalized forms of early modern university self-regulation, the administration is shaped along the internal structures of (Prussian) ministries (Blümel et al. 2011). The academic sector relies on collegial, peerto-peer decision-making in committees which are composed of elected members 
representing the universities' status groups. In this context with its multitude of actors, widely scattered and complementary competences, and many formal as well as informal veto rights (Hüther 2010), swift and far-reaching decisions are unlikely. Instead, problematic preferences, unclear technologies, and the changing and unstable participation in committees (Cohen et al. 1972) concoct an arbitrary mixture of problems, solutions, participants, and decision situations which are responsible for the "institutionalized irresponsibility" (Morkel 2000) of the university.

In contrast to this, the administration operates on the basis of labor division with clearly defined decisional authorities and reporting duties which are supposed to allow for swifter and stricter decisions. However, as the distribution of power between the academic and the administrative sector as well as within the academic sector still is highly fragmented, decision blockades and procrastination are widespread.

(3) A third perspective on the particularities of university communication channels highlights the loose coupling of units (Weick 1976; Orton and Weick 1990). While the administration's structure is predominantly bureaucratic, the academic sector is divided along disciplinary "family resemblances" into de-coupled departments and faculties-i.e., according to scientific distinctions, not organizational needs. R. Paris has labeled this horizontal decoupling the "seriality" of the academic structure and claimed that disciplines and institutes, professorships, and research units operate independently (Paris 2001). Functional interdependencies (like joint study programs or shared research infrastructures) are rare and limited to specific areas. On the one hand, this loose coupling often causes persistent conflicts of interestse.g., concerning the internal distribution of resources. At the same time, it stabilizes the survivability of the university as the existence of each academic unit is independent from the existence of the others. This applies to the level of professorial chairs as well. Even though they must cooperate to a certain degree in providing study programs, they operate quite autonomously in research-regardless of all attempts of university profile building.

(4) Many of the aforementioned structures are related to another feature of university communication channels: the still powerful position of the German professor. First of all, professors belong to a very small group of civil servants who are not obliged to act on orders. This freedom (guaranteed by $\S 5$ of the German constitution) relates to all matters regarding teaching and research and is held responsible for the "basic anarchy" (Kieserling 2001: 114) of the German university. Correspondingly, controlling behavior and work performance of professors is difficult. They are professionals whose practice is autonomous, privileged, based on exclusive knowledge, and controllable only by other members of the profession (Mintzberg 1989; Hüther 2010).

Second, the dominance of professors is underpinned by constitutional law prescribing a majority of professors in all committees deciding on teaching and research issues. The mode of decision-making, thus, does not follow the democratic principle of "one man, one vote" (Stichweh 2005), but resembles the principle of estate-based societies.

Third, professorial staff is "immobilized" (Kühl 2007). While university management (in most of the federal states) can hire professors on their own, they cannot dismiss them due to the tenured position as civil servants. This fact contributes substantially to the university's “organizational weakness” (Hüther 2010; Hüther and Krücken 2011). 
Fourth, attempts at limiting the autonomy of the professoriate through a new salary system, the weakening of the academic senate, personal target agreements, fixed-term equipment for professorships, or through the devolution of the right to appoint professors from ministry to university have not succeeded to the extent envisioned. Instead, a "demo-bureaucracy" (Luhmann 2009: 216) of new posts and committees has emerged. While the reforms were supposed to enable effective governance of professorial teaching and research (e.g., through quality management), they have actually only multiplied the number of players in decision-making without achieving huge steering effects.

Summing up, it shows that the intricate communication channels in German universities defy attempts at fully introducing managerial governance and have rather increased the dispersion of power and the likelihood of garbage can decision-making. At any rate, the assumption that the university's metamorphosis into an organization must promptly lead to swift and bold decisions has proved too optimistic.

\section{Personnel}

The decision premise personnel and the membership conditions in German universities are also shaped by inconsistencies. Especially two aspects merit a closer look: the unusual integration of both performance role and public (or client) role in universities (1) and the features of the professor's and the student's role (2).

(1) The university admits as members both incumbents of the performance role (teachers) and of the public or client role (students) (Luhmann and Schorr 1979). This is unlike other professional organizations: neither schools nor law firms or hospitals admit their clients as members. This particularity is an aftermath of the universitas magistrorum et scholarium, i.e., the medieval community of teachers and students (Krause 1996; Müller 1996). The medieval university was - as already mentioned — a "corporation" like a craft or a trade guild. It took care of all needs and concerns of its members, provided training and socialization for junior staff while admitting trainers (professors) and trainees (students and doctoral candidates) as members (Stichweh 2005). Only in the early modern context of the state-oriented university the two roles started to move apart (Stichweh 1994). Today, both membership roles are shaped in different ways: on the one hand, there is the performance role of the tenured and paid professor who dominates in academic self-governance and has the right to examine and assess students. On the other hand, there is the client role of the student whose membership is temporary, unpaid, tied to the successful passing of exams and whose rights in academic self-governance are comparatively limited. Hence, the university operates with two completely different concepts of membership.

Additionally, the performance role of the professor is divided into the role of a teacher (with the student as client) and into the role of a researcher who does not have a client, but contributes individually to expanding and refining the collective knowledge of his or her disciplinary community. This entails that, on the one hand, professors are members of their scientific community because the latter plays a key role in setting up research agendas and enabling or hindering academic careers. On the other hand, professors are members of the university as the latter provides the necessary resources for research and teaching (money, infrastructure, staff). As a consequence, professors are members of two 
social orders which not alone differ, but partially contradict each other regarding the following dimensions:

- Type and term of membership: while the university integrates professors formally as civil servants with codified rights and obligations, the informal membership in the disciplinary community is based on successful contributions to the collective knowledge of the community. This membership persists as long as the contributions are observed and acknowledged by other members of the scientific community (Gläser 2006).

- Sanctioning violations of membership rules: In case membership rules are violated, the university might resort to formal sanctions (adhortatory letter, suspension from office, etc.) whereas the scientific community's sanction potential is restricted to ignoring the wrongdoer's or underperformer's contributions.

- Membership motives: While the university offers salary payment, teaching and research infrastructures, and other resources, the scientific community controls access to careers and positions (e.g., via disciplinary experts as members of appointment committees), defines the criteria for academic achievements (Paris 2001) and partakes in decisions on the allocation of resources (e.g., as reviewers). As it is not the university, but the scientific community who decides on the allocation of reputation based on discipline-specific standards (Luhmann 1992), it is the latter that paves or blocks the way to academic success.

- Extent of membership: The affiliation to a scientific community is more comprehensive than the affiliation to the university. The community shapes habitus, clothing style, ways of thinking, collegial attitudes (von Wissel 2007), and sometimes even the worldview of its members.

The duality of being a member of the university as an organization and of the scientific community as an informal network differs from membership conditions in most working organizations. Additionally, it bestows professors with a high degree of power (Stichweh 1984) as they can pick the advantages and try to avoid the pitfalls and disadvantages of each membership role.

(2) The public role of students shows several particularities as well as it changes between different role models. Primarily and according to higher education legislation, students are members of the university with specific participation rights (Lindner 2017). Divergent from this membership role are the roles students often take at the same time: they are users of a public-law institution, clients of a professional organization (with regard to teaching), civics within a body politic (as member of academic self-governance), or customers of a company offering educational services (if tuition fees are charged). These roles all refer to types of organization that do not admit their public as members.

If students are conceptualized as users, the university is seen as a public-law institution. Public-law institutions in Germany are a publicly controlled organizations which are founded in the same way as universities, i.e., by passing a law, but do not offer the same extended self-governance. They serve public tasks, but have external beneficiaries or users instead of members (Krause 1996). In Germany, many public libraries are so-called dependent public-law institutions. If the university is considered to be a union of professionals, the students are clients (Stichweh 2005). From this perspective students are not seen as co-producers in teaching 
processes, but as recipients of teaching services. If they are treated as civics, the university is considered to be a kind of body politic. This perspective corresponds to the public nature of German universities and to the fact that some of their decisions (e.g., enrollment, examinations) juridically are administrative acts (Kempen 2017). Eventually, students being customers has been a highly disputed claim in German higher education discourse. However, the debate whose climax was in the period in which all but three federal states had established tuition fees (Graalmann 2009; Degenhardt and Schröder 2009; Das Hochschulwesen 2013) has ceased after the complete abolition of tuition fees in Germany in 2014.

The reflection on the discrepancies of both students' and professors' roles shows that the character of university membership differs significantly from that of regular working organizations and adds to the structural particularity of the German university.

\section{Conclusion and suggestions for future research}

Our reflections on the goal programs, communication channels, and personnel of the German university have verified that its organizational character is consistent with the idea of a multiple hybrid organization. The German university shows inconsistencies, tensions, and contradictions with regard to all its organizational structures. This conceptualization offers several benefits for higher education research.

First, it allows to reconstruct the two main strands of discourse on the organizational character of the university (the normality and singularity argument) in a way that shows that their contradiction is only superficial. The main assumptions of both positions can be integrated consistently in the concept of formal organization that was put forward by systems theory and can be used as a tool for organizational analysis.

Second, as I have tried to show in the main part of this paper, the term "multiple hybrid organization" conveys a heuristic approach for comprehending the organizational structures of the university and, by way of its empirical application, makes for a consistent interpretation of its institutional core.

Third, the integration of the notion "multiple hybrid organization" complements systems theory's perspective on organizations and contributes to theoretical development in modifying the assumption that organizations whose main goal programs refer to two function systems are anomalous. In contrast to this, the concept of multiple hybridity provides a conceptual tool for analyzing organizations with multiple structural frictions and contradictions within the overall framework of systems theory.

Fourth, if the main conceptual lesson learned about hybridity in this paper is that the term "hybrid organization" can be redefined with the aid of Luhmann's organization sociology in a more detailed way, it proves useful for higher education research and, namely, the analysis of universities, as well. While current theories of hybridity in higher education organizations highlight that "concrete universities are hybrid organizations combining elements from different organizational forms "(Bleiklie et al. 2017: 143), the concept of multiple hybridity sharpens the idea of hybridity through defining it as a variety of contradicting structures on all structural levels of universities: on the level of goal programs, conditional programs, communication channels, and personnel. This is not only a contribution to higher education theory, but also a provision of an expedient tool for empirical research. 
However, the idea that the German university is a multiple hybrid organization gives rise to further research questions. In the final part, I will concentrate on five desiderata.

(1) From the perspective of organization sociology, it seems indispensable to examine not only the university structures as separate decision premises, but also their interplay. In how far do developments in higher education and in society at large have an impact on the interdependencies between decision programs, communication channels, and personnel? And vice versa: In how far do internal reforms and intentional changes-for instance of goal programs - affect the other structures?

(2) This calls for a longitudinal study on the development of the organizational model of the German university. Guided by the idea of "multiple hybridity," such an investigation is supposed to trace the development paths of the structural anomalies I have sketched above. As the analysis should serve different research purposes and will require ample research infrastructures, it must be embedded in a broader cooperative investigation of changing internal and external governance regimes in German higher education.

(3) Furthermore, one may ask to what extent other German higher education organizations exhibit public university-like structures. This comparative perspective could be applied to different types of higher education organizations: universities of applied science, private institutions, or church-based universities. While these organizations differ widely in many respects, they coincide (with few exemptions) in their specialization in teaching. Accordingly, their hybridity on the level of goal programs is supposed to be much less pronounced. On the other hand, private institutes as well as church-based organizations have to deal with the expectations of additional functional systems, i.e., the economic system and the religious system. Hence, we can hypothesize that they might exhibit other hybrid structures which is worth analyzing.

(4) Beyond the boundaries of the higher education system, the concept "multiple hybrid organization" could be used to investigate all organizations that produce services for different functional systems - like social enterprises or privately-run hospitals. This is possible because the notion is abstract enough to be applicable to all types of organizations. Comparing other types of hybrid organizations to the German university could show - beyond a mere description of similarities and differences - which organizational forms society has developed in order to address the demands and requirements of different functional systems through organizations.

(5) Eventually, from an international comparative perspective, it will be interesting to contrast the German university to universities from other national higher education systems (which are comparable in terms of size, input and output, developmental status, etc.). A comparison could disclose whether multiple hybridity is a transnational, functional requirement of the university as a global institution or just an idiosyncratic feature of its German version.

Acknowledgements The article is based on research funded by the German Research Foundation (DFG) (KL $1344 / 2-1)$.

Open Access This article is distributed under the terms of the Creative Commons Attribution 4.0 International License (http://creativecommons.org/licenses/by/4.0/), which permits unrestricted use, distribution, and reproduction in any medium, provided you give appropriate credit to the original author(s) and the source, provide a link to the Creative Commons license, and indicate if changes were made. 


\section{References}

Adam, C., Müller, J., Thun, R., Warnecke, W. (Hrsg.) (2010). Die bedingte Universität. Die Institution der Wissenschaft zwischen ,Sachzwang' und ,Bildungsauftrag'. Stuttgart: Schmetterling.

Ahrne, G. \& Brunsson, N. (2009). Complete and incomplete organization. Scores raportserie 2, 2009. SCORE Stockholm Centre for Organizational Research. http://www.score.su.se/polopoly_fs/1.26609.1320939802 !/20092.pdf. Accessed 14 January 2018.

Albert, S., \& Whetten, D. A. (1985). Organizational identity. Research in Organizational Behavior., 7, $263-295$.

Apelt, M., \& Tacke, V. (2012). Einleitung. In M. Apelt \& V. Tacke (Eds.), Handbuch Organisationstypen (pp. 720). Wiesbaden: Springer VS.

Arnold, W. (1970). 5 Minuten vor 12. In L. Kroeber-Keneth (Ed.), Alma mater moribunda oder Ist die Universität noch zu retten? (pp. 7-25). Heidelberg: Quelle \& Meyer.

Ash, M. G. (Ed.). (1999). Mythos Humboldt. Vergangenheit und Zukunft der deutschen Universitäten. Wien, Köln, Weimar: Böhlau.

Baecker, D. (2011). Organisation und Störung. Frankfurt am Main: Suhrkamp.

Battilana, J. \& Lee, M. (2014). Advancing research on hybrid organizing: insights from the study of social enterprise. Academy of Management: Annals, No. 8, 397-441.

Bijsterveld, C., \& van Mouwen, K. (2001). The hybrid university as a concept for the future. Education Law Journal, 1(2), 26-35.

Billis, D. (2010). Hybrid organizations and the third sector: challenges for practice, theory and policy. Basingstoke: Palgrave Macmillan.

Bleiklie, I., \& Kogan, M. (2007). Organization and governance of university. Higher Education Policy, 20, 477493.

Bleiklie, I., Michelsen, S., Krücken, G., \& Frølich, N. (2017). University governance - organisational centralisation and engagement in European universities. In I. Bleiklie, J. Enders, \& B. Lepori (Eds.), Managing universities (pp. 139-165). Cham: Palgrave Macmillan.

Blümel, A., Kloke, K., \& Krücken, G. (2011). Professionalisierungsprozesse im Hochschulmanagement in Deutschland. In A. Langer \& A. Schröer (Eds.), Professionalisierung im nonprofit-management (pp. 105127). Wiesbaden: VS Verlag für Sozialwissenschaften.

Boccardelli, P., Annosi, M. C., Brunetta, F., \& Magnusson, M. (Eds.). (2018). Learning and innovation in hybrid organizations: strategic and organizational insight. Cham, Switzerland: Palgrave Macmillan.

Bode, I. (2003). Multireferenzialität und Marktorientierung? Krankenkassen als hybride Organisationen im Wandel. Zeitschrift für Soziologie, 32(5), 435-453.

de Boer, H., Enders, J., \& Leisyte, L. (2007). Public sector reform in Dutch higher education: the organizational transformation of the university. Public Administration, 85(1), 27-46.

Bogumil, J., Burgi, M., Heinze, R. G. Gerber, Gräf, I., Jochheim, L., Schickentanz, M., \& Wannöffel, M. (2013). Modernisierung der Universitäten. Umsetzungsstand und Wirkungen neuer Steuerungsinstrumente. Berlin edition sigma.

Braun, D. (2001). Regulierungsmodelle und Machtstrukturen an Universitäten. In E. Stölting \& U. Schimank (Eds.), Die Krise der Universitäten, Leviathan Sonderheft (Vol. 20, pp. 243-243). Wiesbaden: Westdeutscher Verlag.

Braun, D., \& Schimank, U. (1992). Organisatorische Koexistenzen des Forschungssystems mit anderen. Journal für Sozialforschung, 32(3-4), 319-336.

Brunsson, N., \& Sahlin-Andersson, K. (2000). Constructing organizations: the example of public sector reform. Organization Studies, 21, 721-746.

Ciesielska, M. (2010). Hybrid Organisation. A study of the Open Source-Business Setting. Copenhagen: Copenhagen Business School Press. http://www.openarchive.cbs.dk/bitstream/handle/10398/8200 /Malgorzata_Ciesielska.pdf?sequence=1. Accessed 14 February 2018.

Clark, B. (1998). Creating entrepreneurial universities: organizational pathways of transformation. Oxford: Elsevier.

von Coelln, C. (2011). Das Binnenrecht der Hochschule. In M. Hartmer \& H. Detmer (Eds.), Hochschulrecht. Ein Handbuch für die Praxis (pp. 283-330). Heidelberg, München, Landsberg, Frechen, Hamburg: C.F. Müller.

Cohen, M. D., March, J. G., \& Olsen, J. (1972). A garbage can model of organizational choice. Administrative Science Quarterly, 17(1), 1-25.

Daxner, M. (1999). Die blockierte Universität. Warum die Wissensgesellschaft eine andere Hochschule braucht. Frankfurt, New York: Campus.

Degenhardt, L., \& Schröder, T. (2009). Studierende als Kunden - Kulturwandel oder Modeerscheinung? HIS Magazin, No.2, Special Edition 40 Years HIS. Hannover: HIS, 11-13. 
Delbecq, A. L., Bryson, J. M., \& van de Ven, A. H. (2013). University governance: lessons from an innovative design for collaboration. Journal of Management Inquiry, 22(4), 382-392.

DiMaggio, P. J., \& Powell, W. W. (1991). The new institutionalism in organizational analysis. Chicago: The University of Chicago Press.

Dörre, K., \& Neis, M. (2010). Das Dilemma der unternehmerischen Universität. Hochschulen zwischen Wissensproduktion und Marktzwang. Berlin: edition sigma.

Drepper, T. (2003). Organisationen der Gesellschaft. Gesellschaft und Organisation in der Systemtheorie Niklas Luhmanns. Wiesbaden: Westdeutscher Verlag.

Enders, J. (2008). Hochschulreform als Organisationsreform. In B. M. Kehm (Ed.), Hochschule im Wandel. Die Universität als Forschungsgegenstand (pp. 231-266). Frankfurt am Main/New York: Campus.

Enders, J., \& Fulton, O. (Eds.). (2002). Higher education in a globalising world. International trends and mutual observation. Dordrecht: Kluwer.

Etzkowitz, H., Webster, A., \& Healey, P. (Eds.). (1998). Capitalizing knowledge: New intersections of industry and academia. Albany: State University of New York Press.

Gläser, J. (2006). Wissenschaftliche Produktionsgemeinschaften. Die soziale Ordnung der Forschung. Frankfurt am Main, New York: Campus.

Graalmann, D. (2009). Der Student als Kunde und König. Sueddeutsche.de, 15.07.2009. http://www. sueddeutsche.de/karriere/marketing-an-universitaeten-der-student-als-kunde-und-koenig-1.165182. Accessed 14 February 2018.

Grunow, D. (2004). Institutionenbildung aus systemtheoretischer Sicht. In A. Benz, H. Siedentopf, \& K. Sommermann (Eds.), Institutionenwandel in Regierung und Verwaltung: Festschrift für Klaus König zum 70. Geburtstag (pp. 34 48). Berlin: Duncker und Humblot.

Hechler, D., \& Pasternack, P. (2012). Hochschulorganisationsanalyse zwischen Forschung und Beratung. die hochschule, special edition. Halle-Wittenberg: Institut für Hochschulforschung (HoF).

Das Hochschulwesen (2013). Forum für Hochschulforschung, praxis und -politik. Themenheft: "Sind Studierende Kunden der Hochschulen?" (6)1-2. Bielefeld: Universitätsverlag Webler.

Huber, M. (2005). Universitäre Anomalie und Autonomiebestrebungen. Eine organisationssoziologische Untersuchung zur aktuellen Universitätsreform in Deutschland. Von der Fakultät für Sozialwissenschaften und Philosophie der Universität Leipzig genehmigte Habilitationsschrift. [Leipzig].

Huber, M. (2012). Die Organisation Universität. In M. Apelt \& V. Tacke (Eds.), Handbuch Organisationstypen (pp. 239-252). Wiesbaden: Springer VS.

Hüther, O. (2010). Von der Kollegialität zur Hierarchie? Eine Analyse des New Managerialism in den Landeshochschulgesetzen. Wiesbaden: VS Verlag für Sozialwissenschaften.

Hüther, O., \& Krücken, G. (2011). Wissenschaftliche Karriere und Beschäftigungsbedingungen. Organisationssoziologische Überlegungen zu den Grenzen neuer Steuerungsmodelle an deutschen Hochschulen. Soziale Welt, 62, 305-325.

Kehm, B. M., \& Teichler, U. (Eds.). (2013). The academic profession in Europe: new tasks and new challenges. Dordrecht et al.: Springer.

Kempen, B. (2017). Grundfragen des institutionellen Hochschulrechts. In M. Hartmer \& H. Detmer (Eds.), Hochschulrecht. Ein Handbuch für die Praxis (pp. 1-52). Heidelberg, München, Landsberg, Frechen, Hamburg: C.F. Müller.

Kern, H. (2005). Über die Kunst, eine Universität zu steuern. In Göttinger Universitätsbund (Ed.), Göttinger Universitätsreden. Vol. 97, (35-48). Göttingen: Vandenhoeck \& Ruprecht.

Kerr, C. (2001). The uses of the university (5th ed.). Cambridge, Massachusetts: Harvard University Press.

Kieserling, A. (2001). Bildung durch Wissenschaftskritik: Soziologische Deutungen der Universitätsidee in den sechziger Jahren. In E. Stölting \& U. Schimank (Eds.), Die Krise der Universitäten, Leviathan Sonderheft (Vol. 20, pp. 81-118). Wiesbaden: Westdeutscher Verlag.

Kleimann, B. (2016). Universitätsorganisation und präsidiale Leitung. Führungspraktiken in einer multiplen Hybridorganisation. Wiesbaden: Springer.

Krause, P. (1996). Das studentische Rechtsverhältnis. In C. Flämig et al. (Eds.), Handbuch des Wissenschaftsrechts (pp. 547-570), second revised and extended edition. Wiesbaden, Berlin: Springer.

Krücken, G. (2011). Soziologische Zugänge zur Hochschulforschung. die hochschule. No.2, 102-116.

Krücken, G., \& Meier, F. (2006). Turning the university into an organizational actor. In G. S. Drori, J. W. Meyer, \& H. Hokyu (Eds.), Globalization and organization. World society and organizational change (pp. 240257). Oxford: Oxford University Press.

Kühl, S. (2007). Von der Hochschulreform zum Veränderungsmanagement von Universitäten - LuhmannNacherzählung unter dem Gesichtspunkt der Reformierbarkeit von Universitäten. In P. Altvater, Y. Bauer, \& H. Gilch (Eds.), Organisationsentwicklung in Hochschulen (pp. 1-10). Hannover: HIS-Forum Hochschule.

Kühl, S. (2013). Organizations: A Systems Approach. Farnham, Surrey, Burlington, VT: Gower. 
Laske, S., \& Meister-Scheytt, C. (2003). Wer glaubt, dass Universitätsmanager Universitäten managen, glaubt auch, dass Zitronenfalter Zitronen falten. In J. Lüthje \& S. Nickel (Eds.), Universitätsentwicklung Strategien, Erfahrungen, Reflexionen (pp. 163-187). Frankfurt am Main: Peter Lang.

Lewis, L., \& Altbach, P. (1996). Faculty versus administration: a universal problem. Higher Education Policy, $9(3), 255-258$.

Lindner, J. F. (2017). Rechtsfragen des Studiums. In M. Hartmer \& H. Detmer (Eds.), Hochschulrecht. Ein Handbuch für die Praxis (pp. 650-725). Heidelberg, München, Landsberg, Frechen, Hamburg: C.F. Müller.

Luhmann, N. (1964). Funktionen und Folgen formaler Organisation. Berlin: Duncker und Humblot.

Luhmann, N. (1984). Soziale Systeme. Grundriß einer allgemeinen Theorie. Frankfurt am Main: Suhrkamp.

Luhmann, N. (1988). Organisation. In W. Küpper \& G. Ortmann (Eds.), Mikropolitik - Rationalität, Macht und Spiele in Organisationen (pp. 165-185). Wiesbaden: Springer VS.

Luhmann, N. (1992). Die Wissenschaft der Gesellschaft. Frankfurt am Main: Suhrkamp.

Luhmann, N. (1998). Die Gesellschaft der Gesellschaft. Frankfurt am Main: Suhrkamp.

Luhmann, N. (2006). Organisation und Entscheidung (2nd ed.). Wiesbaden: VS Verlag für Sozialwissenschaften.

Luhmann, N. (2009). Soziologische Aufklärung. Soziales System, Gesellschaft, Organisation. Wiesbaden: Springer VS.

Luhmann, N., \& Schorr, K. E. (1979). Reflexionsprobleme im Erziehungssystem. Stuttgart: Klett-Cotta.

Luhmann, N., \& Schorr, K. E. (1982). Das Technologiedefizit der Erziehung und die Pädagogik. In N. Luhmann \& K. E. Schorr (Eds.), Zwischen Technologie und Selbstreferenz (pp. 11-40). Frankfurt am Main: Suhrkamp.

Mazza, C., Quattrone, P., \& Riccaboni, A. (2008). Introduction. Found in translation? The persistence of the university as institution. In C. Mazza, P. Quattrone, \& A. Riccaboni (Eds.), European universities in transition: issues, models and case (pp. 1-14). Cheltenham, Northampton: Edward Elgar Publishing Limited.

Meier, F. (2009). Die Universität als Akteur. Zum institutionellen Wandel der Hochschulorganisation. Wiesbaden: VS Verlag für Sozialwissenschaften.

Meier, F., \& Schimank, U. (2010). Organisationsforschung. In D. Simon, A. Knie, \& S. Hornbostel (Eds.), Handbuch Wissenschaftspolitik (pp. 106-117). Wiesbaden: Springer VS.

Meyer, J. W., \& Rowan, B. (1977). Institutionalized organization. Formal structure as myth and ceremony. The American Journal of Sociology, 83(2), 340-363.

Meyer, J. W., Drori, G. S., \& Hwang, H. (2006). World society and the proliferation of formal organization. In J. W. Meyer, G. S. Drori, \& H. Hwang (Eds.), Globalization and organization. World society and organizational change (pp. 25-49). New York: Oxford University Press.

Meyer, J. W., Ramirez, F. O., Frank, D. J., \& Schofer, E. (2007). Higher education as an institution. In P. J. Gumport (Ed.), Sociology of higher education: contributions and their contexts (pp. 187-221). Baltimore, Maryland: Johns Hopkins University Press.

Mintzberg, H. (1989). Mintzberg on management. Inside our strange world of organizations. New York et al.: The Free Press.

Mongelli, L., Rullani, F., \& Versari, P. (2017). Hybridisation of diverging institutional logics through commonnote practices: an analogy with music and the case of social enterprise. Industry and Innovation, 24(5), 492514.

Morkel, A. (2000). Die Universität muss sich wehren. Ein Plädoyer für die Erneuerung. Darmstadt: Wissenschaftliche Buchgesellschaft.

Mouwen, K. (2000). Strategy, structure and culture of the hybrid university: towards the university of the $21^{\text {st }}$ century. Tertiary Education and Management, 6(1), 47-56.

Müller, R. A. (1996). Geschichte der Universität. Von der mittelalterlichen Universitas zur deutschen Hochschule. Hamburg: Nikol.

Musselin, C. (2007). Are universities specific organisations? In G. Krücken, A. Kosmützky, \& M. Torka (Eds.), Towards a multiversity? Universities between global trends and national traditions (pp. 63-86). Bielefeld: Transcript Verlag.

Nickel, S. (2007). Partizipatives Management von Universitäten. München und Mering: Rainer Hampp Verlag.

Orton, J. D., \& Weick, K. E. (1990). Loosely coupled systems: a reconceptualization. Academy of Management Review, 15(2), 203-223.

Pache, A., \& Santos, F. (2013). Inside the hybrid organization: selective coupling as a response to competing institutional logics. Academy of Management, 56(4), 972-1001.

Paletschek, S. (2001). Die permanente Erfindung einer Tradition - die Universität Tübingen im Kaiserreich und in der Weimarer Republik. Stuttgart: Steiner.

Paris, R. (2001). Machtfreiheit als negative Utopie. Die Hochschule als Idee und Betrieb. In E. Stölting \& U. Schimank (Eds.), Die Krise der Universitäten (pp. 194-222). Wiesbaden: Westdeutscher Verlag.

Pellert, A. (1999). Die Universität als Organisation. Die Kunst, Experten zu managen. Wien, Köln, Graz: Böhlau. 
Rehberg, K. (2009). Universität als Institution. In F. J. Felten, A. Kehnel, \& S. Weinfurter (Eds.), Institution und Charisma (pp. 9-32). Köln, Weimar, Wien: Böhlau.

Reichwald, R. (2000). Organisations- und Führungsstrukturen zur Stärkung der Wettbewerbsfähigkeit der Universität von morgen. In S. Laske et al. (Eds.), Universität im 21. Jahrhundert (pp. 315-335). München und Mering: Rainer Hampp Verlag.

Sathe, V. (1985). Culture and related corporate realities. Text, cases, and readings on organizational entry, establishment, and change. Homewood, Ill: Irwin.

Schelsky, H. (1963). Einsamkeit und Freiheit. Idee und Gestalt der deutschen Universität und ihrer Reformen. Reinbek: Rowohlt.

Schimank, U. (1995). Hochschulforschung im Schatten der Lehre. Frankfurt, New York: Campus Verlag.

Schimank, U. (2001). Festgefahrene Gemischtwarenläden - Die deutschen Hochschulen als erfolgreich scheiternde Organisationen. In E. Stölting \& U. Schimank (Eds.), Die Krise der Universitäten (pp. 223242). Wiesbaden: Westdeutscher Verlag.

Schimank, U. (2005). Die akademische Profession und die Universitäten: New Public Management und eine drohende Entprofessionalisierung. In T. Klatetzki \& V. Tacke (Eds.), Organisation und Profesion (pp. 143164). Wiesbaden: VS Verlag für Sozialwissenschaften.

Schimank, U. (2008). Hochschule als Institution: Gussform, Arena und Akteur. In K. Zimmermann \& S. MetzGöckel (Eds.), Perspektiven der Hochschulforschung (pp. 157-163). Wiesbaden: VS Verlag für Sozialwissenschaften.

Schreiterer, U. (2010). Die überforderte Universität. In J. Kaube, \& J. F. K. Schmidt (Eds.), Die Wirklichkeit der Universität (pp. 438-443). Soziale Systeme. Zeitschrift für soziologische Theorie, 16(2). Stuttgart: Lucius und Lucius.

Seeber, M., Lepori, B., Montauti, M., Enders, J., de Boer, H., Weyer, E., Bleiklie, I., Hope, K., Michelsen, S., Nyhagen Mathisen, G., Frølich, N., Scordato, L., Stensaker, B., Waagene, E., Dragsic, Z., Kretek, P., Krücken, G., Magalhães, A., Ribeiro, F. M., Sousa, S., Veiga, A., Santiago, R., Marini, G., \& Reale, E. (2015). European universities as complete organizations? Understanding identity, hierarchy and rationality in public organizations. Public Management Review, 17(10), 1444-1474.

Simon, H. A. (1947). Administrative behavior: a study of decision-making processes in administrative organization. New York: Macmillan.

Simsa, R. (2001). Gesellschaftliche Funktionen und Einflussformen von Nonprofit-Organisationen. Eine systemtheoretische Analyse. Frankfurt am Main u. a.: Peter Lang.

Stichweh, R. (1984). Zur Entstehung des modernen Systems wissenschaftlicher Disziplinen. Physik in Deutschland 1740-1890. Frankfurt am Main: Suhrkamp.

Stichweh, R. (1994). Wissenschaft, Universität, Professionen. Soziologische Analysen. Frankfurt a. M.: Suhrkamp.

Stichweh, R. (2001). Die moderne Universität in einer globalen Gesellschaft. In E. Stölting \& U. Schimank (Eds.), Die Krise der Universitäten (pp. 346-360). Wiesbaden: Westdeutscher Verlag.

Stichweh, R. (2005). Neue Steuerungsformen der Universität und die akademische Selbstverwaltung. In U. Sieg \& D. Korsch (Eds.), Die Idee der Universität heute (pp. 123-134). München: K. G. Saur.

Stichweh, R. (2009). Autonomie der Universitäten in Europa und Nordamerika: Historische und systematische Überlegungen. In J. Kaube (Ed.), Die Illusion der Exzellenz. Lebenslügen der Wissenschaftspolitik (pp. 3849). Berlin: Klaus Wagenbach.

Stichweh, R. (2010). The institutional structure of the German university. https://www.academia.edu/10233761 /The_Institutional_Structure_of_the_German_University_2010. Accessed 25 February 2018.

Tacke, V. (2001). Funktionale Differenzierung als Schema der Beobachtung von Organisationen. Zum theoretischen Problem und empirischen Wert von Organisationstypologien. In V. Tacke (Ed.), Organisation und gesellschaftiche Differenzierung (pp. 141-169). Wiesbaden: Westdeutscher Verlag.

Tahar, S., Niemeyer, C., \& Boutellier, R. (2012). Transferral of business management concepts to universities as ambidextrous organisations. Tertiary Education and Management., 14(4), 289-308.

Weber, M. (1968). Gesammelte Aufsätze zur Wissenschaftslehre (3rd ed.). Tübingen: Mohr.

Weick, K. (1976). Educational organizations as loosely coupled systems. Administrative Science Quarterly, 21(1), 1-19.

Wilkesmann, U., \& Schmid, C. (Eds.) (2012): Hochschule als Organisation. Wiesbaden: Springer VS.

Wissel, C. v. (2007). Hochschule als Organisationsproblem. Neue Modi universitärer Selbstbeschreibung in Deutschland. Bielefeld: Transcript.

Zucker, L. G. (1977). The role of institutionalization in cultural persistence. American Sociological Review, 42(5), 726-743. 